\title{
Conceptual Framework for Financial Reporting: Problems and Prospects
}

\author{
Kim Tsygankov $\bowtie$ \\ Dr. Sci. (Econ.), Associate professor, Department of Audit, Accounting and Finance \\ $\underline{\text { ORCID }}$ \\ E-mail: kim492005@yandex.ru \\ Federal State-Funded Educational Institution of Higher Education Novosibirsk State Technical University, Novosibirsk, \\ Russia
}

Journal of Corporate Finance Research, Vol. 15, No. 1, pp. 37-47 (2021)

For citation: Tsugankov, K. (2021) «Conceptual Framework for Financial Reporting: Problems and Prospects», Journal of Corporate Finance Research / Корпоративные Финансы | ISSN: 2073-0438, 15(1), сc. 37-47. doi: 10.17323/j.jcfr.2073-0438.15.1.2021.37-47.

Received 15 January 2021 | Peer-reviewed 13 February 2021 | Accepted 20 February 2021 


\section{Abstract}

The objective of this paper is to define the theoretical basis and clarify the fundamental concept of the Conceptual Framework for Financial Reporting (CFFR). This is because the theoretical basis for CFFR has not been properly defined, and the articulation of the fundamental concept in the document does not correspond to its actual meaning. In clarifying, we will analyse these attributes from a critical perspective and propose an alternative articulation.

We apply a research method widely used in the USA based on semiotics, which construes accounting as a business language and requires analysis of the key accounting concepts from three viewpoints: syntactic, semantic and pragmatic. Two different theories form the theoretical basis for CFFR: the organisation theory and the residual equity theory. We further propose that the articulation of the fundamental concept of "objective of financial reporting" is self-contradictory, which is aggravated by the fact that the document deals with users of financial reporting and their objectives.

We identify major drawbacks in both theories. The organisation theory requires specific financial reporting which is incompatible with standardisation, and the residual equity theory is extremely difficult to understand and is not completely satisfactory for any of its user groups. These drawbacks and inaccuracies occlude understanding of CFFR and financial reporting.

As a result, we propose that it is advisable to do the following when developing the next version of CFFR:

- define the uniform theoretical basis in CFFR clearly;

- $\quad$ use the proprietary theory as the uniform theoretical basis;

- the definition of financial reporting oriented to informational needs of company owners should be the fundamental concept of CFFR.

This will enable CFFR and financial reporting to be simpler understand and the primary needs of all user groups will be satisfied.

Keywords: Conceptual Framework for Financial Reporting, objective of financial reporting, understandability of financial reporting, financial reporting users, proprietary theory, organisation theory, residual equity theory 


\section{Introduction}

\section{Conceptual Framework for Financial Reporting: History and Purpose}

In March 2018 the London International Accounting Standards Board (IASB) published the document 'Conceptual Framework for Financial Reporting' (translated into Russian as «Концептуальные основы представления финансовых отчетов» $\left.{ }^{1}\right)[1]$ (hereinafter "CFFR-2018"). It is the fourth edition of this document. The first edition was developed in the USA by the Financial Accounting Standards Board (FASB). It was developed in stages, and published in six consecutive chapters (SFAC1-SFAC6) ${ }^{2}$ between 1978-1985. In 1989 the London Board published the second edition of this document (with minor modifications) titled the 'Framework for the Preparation and Presentation of Financial Statements' [2]. The third edition, titled 'Conceptual Framework for Financial Reporting' was issued in 2010 [3]. We apply the latter title in this paper for all editions of this document because it has been used three times and is the shortest. A lot of research papers have studied issues related to CFFR, for example those by S.A. Zeff [4] and T.N. Malafeeva [5].

CFFR was designated for development of a high quality standards system based on a set of unified theoretical points: First FASB described CFFR as a "constitution, a coherent system of interrelated objectives and fundamentals that can lead to consistent standards and that prescribes the nature, function, and limits of financial accounting and financial statements" [6, p. 376].

Thus, CFFR is a theoretical framework for the standardisation process, and at the same time is an international version of the financial accounting theory. The fact that convergence of IFRS and GAAP started with the development of a consolidating edition of CFFR is indicative of this document's importance. "A joint conceptual framework project of IASB and FASB started in 2002 as a direct result of the Norwalk Agreement, according to which the Boards agreed to develop together the future general standards... Obviously, the general conceptual foundation is a prerequisite for such work" [7, p. 497-498].

The latest edition of CFFR received widespread criticism: "The International Accounting Standards Board (IASB) published the latest edition of its Conceptual Framework in March 2018. The IASB would not claim that they are at "the end of all our exploring" [6, c. 374]. "The latest edition will not be the latest one. We can hear again: There you go again!... The IASB developers are unlikely to welcome the idea of continuing their work. After all the time and effort spent on CFFR they may feel "lightheaded" at the idea that they have to start all over again" [6, p. 399]. However, the authors of CFFR-2018 (art. SP1.4) leave open the possibility of working on a new edition: "The Conceptual Framework may be revised from time to time on the basis of the board's experience of working with it." Given the foregoing, we hope that this paper will help to improve and add value to such an important document.

\section{Problem Defining}

There is no doubt that the CFFR authors followed some theory, or a combination of theoretical concepts which we will refer to as the 'theoretical basis'. Unfortunately, this basis is not described even once in the CFFR text. However, the first article of this document defines the fundamental concept and asserts that "other aspects of the Conceptual Framework ... flow logically" [1, art. 1.1]. If this is true, defining the theoretical basis is unnecessary, as it may also be inferred from the fundamental concept.

However, an analysis of the fundamental concept raises doubts that such a conclusion is justified. First, its formal denomination - 'the objective of financial reporting' appears inappropriate. In fact, only subjects endowed with intelligence and willpower may have objectives. Reporting (financial or non-financial) may have contents, purposes, and functions. Several famous authors [8, p. 151; 9, p. 9; 10, p. 11] have criticised the use of this phrase but it was never changed. Second, the objective (of submitting) financial reporting in all CFFR editions actually implied the financial reporting of users, and their objectives. In other words, both terms describing the fundamental notion, the previous and the new one, fail to render its meaning.

The research objective and method. The objectives of the paper are: a) to identify the theoretical basis which CFFR authors followed and its inherent drawbacks; b) to analyse the fundamental concept from a critical point of view; c) to offer an alternative theoretical basis and an alternative fundamental concept.

The paper applies the method adopted by US accountants $^{3}$ derived from semiotics (study of signs) and which has been applied successfully in recent decades. This method implies interpretation of accounting as a business language, and requires analysis of the key accounting concepts from three viewpoints: syntactic (for technical correspondence to language rules), semantic (from the point of view of meaning) and pragmatic (from the point of view of practical consequences of the use of the pertninent concept) [8, p. 97-98; 11, p. 19].

\footnotetext{
${ }^{1}$ CFFR 2010 and 2018 have the same title: Conceptual Framework for Financial Reporting and are translated аs «Концептуальные основы финансовой отчетности». This is the translation of CFFR-2010, as given by the Russian Ministry of Finance in 2014. Despite efforts, the author found it impossible to get an explanation (even from translators of this document) as to why the same title of CFFR 2018 had been translated in a different way.

${ }^{2} \mathrm{SFAC}-$ statements of financial accounting concepts.

${ }^{3}$ US accountants are acknowledged leaders of the philosophy of global accounting, and made arguably the greatest contribution to development of all CFFR editions.
} 


\section{The Main Research Findings}

Two separate theories are used as the theoretical basis of CFFR: the 'organisation' theory [12, p. 5] and the 'residual equity' theory which is a compromise between the organisation theory and the proprietary theory [11, p. 483]. The organisation theory was used to define the fundamental concept of CFFR, the residual equity theory - to identify the elements of financial reporting.

The use of two theories may be explained, for example, by the fact that the American version of CFFR was developed in phases: in 1978 the first chapter (SFAC1) was published, defining the fundamental concept - the objective of financial reporting; in 1980 the third chapter (SFAC3) was published, defining the financial reporting elements [13, p. 142]. Subsequently, in 1985 SFAC3 was replaced with SFAC6. There are reasons to believe that SFAC1, SFAC3 and SFAC6 were not just developed in different time periods, but were also written by different specialists. Issuers of the three international CFFR editions were wary of addressing the initial theoretical foundations and only clarified and developed derivative concepts $[6$, p. $375 ; 14$, p. $461 ; 15$, p. 238]. In spite of its self-contradictoriness the denomination of the fundamental concept - "the objective of financial reporting" was not reviewed either.

From the syntactic point of view the term "objectives of financial reporting" fails to meet the requirements of scientific language: as stated earlier, only subjects endowed with intelligence and willpower may have objectives, whereas reporting (financial or non-financial) may have contents, purposes, and functions. From the semantic point of view, "objectives of financial reporting" in CFFR are understood as financial reporting users and their objectives. The latter point is an implication of the organisation theory, which superseded the proprietary theory in the USA in the 1970s, exactly at the period of the final stage of SFAC1 development. According to the organisation theory, financial reporting users are divided into groups pursuing different objectives and having equal rights to getting the reporting in the format which facilitates achievement of their objectives. Each user group needs special financial reporting, with its forms and procedure for calculating the key indicators in accordance with its underlying theoretical basis. As such, before we deal with types of financial reporting it is necessary to define the user group for which such a reporting style is intended. This logic resulted in the fact that the objectives of financial reporting users, labelled for whatever reason (probably, for brevity) as the "objective of financial reporting" became the fundamental concept of CFFR.

It is, in principle, unacceptable to use two different theories for development of the same document. The authors should base their work on one theory. It is impossible to apply the organisation theory for this purpose, as it requires making reporting of several types which is incompatible with standardisation. The residual equity theory requires one type of reporting intended to satisfy, as far as possible, the needs of all user groups. This theory is compatible with standardisation but does not meet in full the interests of any of the user groups and is an intricate prospect.

It is reasonable to define in the opening section of CFFR the theoretical basis for the concepts of this document. The proprietary theory is preferable as the theoretical basis of CFFR. It is well-known (especially in the USA), simple, and implies making the financial reporting intended to satisfy the interests of company owners. Thus, the proprietary theory fully meets the interests of the main group of financial reporting users. Besides this, according to many scientists (and in the opinion of this author) the theory which satisfies the needs of owners meets the main interests of all other user groups. On the basis of this reasoning the definition of financial reporting intended to meet owners' interests should be the fundamental concept of CFFR.

In the second section (after the introduction) two main theories of US accountants are analysed (the proprietary theory and the organisation theory), as well as the compromise theories based on them. In the third - to fifth sections the fundamental concept of CFFR is analysed and the main theoretical contradiction of the whole document is identified. In the sixth section the author's approach to choosing the theoretical basis of CFFR is stated. The final section briefly describes the conclusions and limitations of the paper.

\section{Theoretical Views of US Accountants}

Two competing theories, popular in the USA, greatly influenced the development of CFFR and the choice of its fundamental concepts: the proprietary theory and the organisation theory.

\section{The Proprietary Theory and the Organisation Theory}

In the $19^{\text {th }}$ century, the main users of accounting reports were company owners. Predictably, in the first accounting theory developed in the American milieu in 1841, the field was considered from the owners' point of view. An American accountant, T. Jones [16], was its author. The theory was outlined rather vaguely, applying the terms of accounting records. Following in his footsteps, B.F. Foster [17] and Swiss accountants F. Hügli [18] and J.F. Schär [19] offered a similar theory, using terms of accounting records and formulating it in a slightly different way. This theory was articulated in 1927 by applying terms of financial reporting in the USA by H. Hatfield [20], and in Russia - by $\mathrm{K}$. Tsygankov [21] at the beginning of the $21^{\text {st }}$ century. In English-speaking countries this theory is called the proprietary theory. According to it, the principal users of financial reporting are company owners [22, p. 196-197]. Reporting items are made from the point of view of owners and are intended to measure and analyse their welfare expressed in the following balance equation:

Assets - Liabilities = Equity (Net Assets or Property). 
Assets are considered as money and property at the owner's disposal, and accounts payable are considered as the owner's liabilities to lenders. According to H. Hatfield "accounts payable are negative assets while equity in the initial accounting equation is the owner's net welfare" [cit. ex 11, p. 480]. When a company is founded, equity equals the sum of the amount invested by the owner. Equity subsequently changes due to profit and expenditure and the owner's transactions (additional equity infusions and withdrawn dividends).

In accordance with the proprietary theory, profit is anything increasing the owner's welfare, and expenditure is anything reducing it. We shall here point out that the pertinent definitions describe owner's welfare instead of corporate equity. Dividends withdrawn by owners reduce corporate equity but are not expenditures, because they do not reduce owner's welfare ${ }^{4}$. For the same reason, equity infusions which increase corporate equity (but not owner's welfare) are not considered to be profit [11, p. 480-481]. This theory was named so because it focused on owner's welfare instead of the company or its equity.

On the cusp of the $19^{\text {th }}$ and $20^{\text {th }}$ centuries the organisation theory was formulated in the US, which competed with the proprietary theory. Defenders of the organisation theory considered it inadmissible (and likely unethical) to separate owners from other users of financial reporting, e.g. lenders, business partners, employees, and government [22, p. 201]. Moreover, whenever possible, they understated the leading role of company owners. They considered a company as an independent entity, and a "business interested in its (own) survival. In order to survive, a company should comply with legislation and maintain good relations with providers of debt capital and equity. Attracting capital providers, hence, gaining profit, is necessary for survival but it is not the only corporate objective" [ibidem]. Reporting items are considered in this theory from the company point of view.

Corporate assets belong to the company, not its shareholders; both debt capital and equity capital are corporate liabilities. Consequently, the balance formula appears as follows:

\section{Assets = Liabilities. (2)}

The place of profit in organisation theory is occupied by added value, represented by the difference between the market value of manufactured products and the cost of off-loaded goods and services. Thus, all company employees, owners, creditors, and the government (through the taxation system) are recipients of a part of the company's added value. "This added value is a "pie", divided among all participants who have contributed to its 'making"' [11, p. 224]. All these groups are equal users of financial reporting. For each group, its own financial reporting is rendered with regard to its set of items, its own procedure for calculation, and hence, its own theory. So, before dealing with financial reporting, its contents and theory, it is necessary to define the users for which it is intended. Consequently, the fundamental concept of CFFR should be defining of its users.

\section{Compromise Theories}

In the competition of two theories, the organisation theory prevailed. R. Mattessich [23, p. 29-30] thinks that it took place in the latter half of the $20^{\text {th }}$ century. C. Van Mourik is of the same opinion: "The proprietary theory was a popular topic in magazines from the 1930s to the 1960s... But since the 1970s the proprietary theory has been collecting dust in accounting theory textbooks, or dropped out of view from the majority of scientists" [22, p. 193]. Issuers of CFFR-2010 pointed out the directly preferability of the organisation theory: The boards ${ }^{5}$ decided that corporate financial reporting should be prepared from the point of view of the company instead of the point of view of its owners or a certain proprietary class" [12, p. 5].

However, the proprietary theory lives on as a part of the theories which are a compromise between the proprietary theory and the organisation theory. At present, FASB and IASB uphold the residual equity theory" [11, p. 486] which is "a kind of compromise between the proprietary theory and the organisation theory" $[11, \text { p. 483 }]^{6}$. Compromise theories imply making one type of reporting oriented to the interests of several user groups.

One of the first compromise theories was offered by W. Paton, who thought that reporting should be made for two user groups: owners (shareholders) and bond holders. "The profit and loss statement should be drawn up in a way that shows the "net profit" accrued by all capital providers: shareholders as well as bond holders. Therefore, interest payments referred to documents of indebtedness should be indicated in the same way as dividends: as distribution of profits, and not expenditure when profits are gained. Interest is the lenders' profit" [cit. ex: 4, p. 268-269]. S. Zeff made the following comment: "Today everybody thinks that interest charges should be indicated in the profit and loss statement as expenditure. Nevertheless, Paton's position is justified if we define net profit as investors' revenue and equity securities and debt securities" [4, p. 269].

In the post-war years, the securities which combine functions of equity and debt instruments were offered. The reference cited at [11, p. 479] presents a table showing the types and characteristics of such securities: preferred share, convertible preferred share, convertible bond, warrant, share subject to right of return etc. In total, the table

\footnotetext{
${ }^{4}$ In this case the owners take assets from one pocket and put into another.

${ }^{5}$ The development of CFFR-2010 was a joint project of the London IASB and the American Financial Accounting Standards Board (FASB).

${ }^{6}$ Unfortunately, the description of this most important theory takes only a page and a half in the huge monograph of the leading American theorists [11, p. 483-484].
} 
represents 13 types of securities which differ in six parameters. It is possible that since the year of the publication of the table (1992) new securities have been introduced. This means that attempts to keep pace with the increasing variety of securities types and interests of the users behind them will complicate theories.

Let us show the complexity of the residual equity theory through the following example. As per CFFR-2018 art. 4.63: "Equity is a residual share in total corporate assets after deducting all company liabilities"7. In our opinion, this definition is as self-contradictory as that of the "objective of financial reporting". In fact, the result of deduction (including the deduction of liabilities from assets) is difference, not a share. Share is a relative index, while equity is an absolute index. The term "residual share" is not used in any science. Finally, the decisions taken by users are economic ones - equity is one of the most important economic concepts, while the definition contains not a spark of economic content.

The colleagues with whom we consulted failed to explain the meaning of this definition- everybody assumed that it was a mistranslation. However, the translators of CFFR into Russian asserted that the translation was correct. We have no reason to doubt this, because the authenticity of the translation was affirmed by IASB.

In the opinion of C. Van Mourik, the theoretical basis of CFFR is not clear enough even to the authors of this document: "The joint project of IASB and FASB aims at the updating and convergence of the existing conceptual frameworks of FASB and IASB. In their draft project related to the objective of financial reporting, the boards added the following comment: "The boards decided that corporate financial reporting should be prepared from the point of view of the company, instead of the point of view of its owners or a certain proprietary class". Comments of concerned parties showed that the boards have no idea of the differences between these two approaches and in the final edition the reference to these theories will probably be excluded. If even the setters of the standard makers had no clear understanding of these theories it would be reasonable to conduct a thorough analysis casting some light on previous discussions" [22, p. 192].

\section{Criticism of the Organisation Theory}

At first sight, the organisation theory is very attractive. It implements the idea of equality of all user groups: no single group is preferred over others, and each group has its own reporting which takes into consideration interests of such group to the maximum extent.

In our opinion, the theory's drawbacks are of no less importance. First, it is incompatible with standardisation which renders it inadmissible for CFFR makers. Second, it significantly complicates the theory, terminology and understanding of financial reporting. Let us turn our attention to the latter.
Accounting in the USA is proudly called a business language. At the same time, they acknowledge that the language quality leaves room for improvement. "FASB is constantly working upon elimination from the balance-sheet of the items which have no clear meaning content. However, in spite of all FASB efforts many accounting concepts still have no semantic content" [11, p. 483].

One such concept - "profit" according to SFAC 1 (par. 43 ) is the "fundamental concentration of financial reporting” [cit. ex: 11, p. 203]. However, CFFR editions offer no definition of profit. One of the reasons is the organisation theory, which originated five various concepts of profit: added value, corporate net profit, investor's net profit, shareholders' net profit, and ordinary shareholders' net profit [11, p. 227-228]. Each profit concept has its own method of calculation, of indicating in reporting and interpretation of this indicator. This impedes understanding of the essence of profit, even to professionals: "The greatest difficulty in discussing alternative methods of the accounting of profit is that the authors, as a rule, fail to indicate the profit concept which they use" [11, p. 229-230].

A rhetorical question arises: if the meaning of the most important reporting indicators is not clear enough even to professionals, how it is possible for users to grasp such meaning. Indeed, do users need a theory which complicates understanding of financial information so much, and hence, complicates taking a sound economic decisions?

In our opinion, the organisation theory just makes semblance of equality presenting, for example, income of employees in the reporting, together with owners' dividends. At the same time, the amount of employees' income and their actual status will still differ from the income and status of owners. On the other hand, understandability of reporting for users (all users) in this case diminishes significantly along with the quality of economic decisions taken without understanding.

Another factor impeding understanding of CFFR is that its fundamental concept, for unfathomable reasons ${ }^{8}$, is called 'defining the objective of financial reporting' instead of 'defining users'. This is shown below, in a detailed analysis of this concept.

\section{Syntactic Analysis of the Fundamental Concept of CFFR 2018}

1.1. "The objective of submitting financial reporting forms a fundamental basis for the Conceptual Framework. Other aspects of the Conceptual Framework ... flow logically from the above objective" [1].

Note that the second word of the above definition, which is crossed out, was added by the translator. This word is not used in the original text and we are still discussing the "objective of financial reporting". We mentioned above

\footnotetext{
${ }^{7}$ The same definition is given in all previous CFFR editions.

${ }^{8}$ The identification of these causes requires a separate research study involving English speakers.
} 
that the translator also added the word "submitting" to the document title as well. We shall not conjecture the cause of this translator's decision. Let us analyse the wording of the original text of all CFFR editions since 1978.

Analysis. In the first paragraph of CFFR the following is stated clearly: the concept of the "objective of financial reporting" is the fundamental one, all other aspects of this document flow logically from it. However, from our point of view, the word combination "objective of financial reporting" does not meet the requirements of scientific or even everyday language. Probably, it is an oxymoron such as "vest sleeves". The issue is that any reporting (as well as any documents, instruments and other inanimate objects) don't and cannot have objectives. Subjects endowed with intelligence and willpower may have objectives.

Russian scientists with whom the author shared this opinion after some doubt agreed but presumed that it was a translation error. However, an analysis of foreign sources led the author to the conclusion that, most likely, the error was made in the original text. This is confirmed by the opinion of famous theorists, English speakers and supporters of the English-American accounting school: "In the strict sense financial reporting cannot have objectives; only people who require making reports and using them have objectives" 9 [8, p. 151]. D. Solomons ${ }^{10}$ emphatically avoided the wording "objectives of financial reporting" and replaced it with "functions of financial reporting" [9, p. 9]. In 1988 according to S. Zeff [4, p. 302], Australian authors G.P. Whittred and I.R. Zimmer declared the following: a) financial reporting has no objective: it has functions" and b) "the function of financial reporting is agency cost reduction" [10, p. 11].

So, reporting can have functions, contents and purpose. While objectives pertain to reporting users. It is shown below that the next CFFR articles implied users.

\section{Semantic Analysis of the Fundamental Concept of CFFR-2018}

The objective of submitting ${ }^{1+}$ general purpose financial reporting - to provide financial information about the reporting entity that is useful to existing and potential investors, lenders, and other creditors in making decisions about providing resources to the entity". Those decisions involve:

(a) buying, selling, or holding equity and debt instruments;

(b) providing or settling loans and other forms of credit;

(c) exercising rights to vote on management's actions.
In fact, art. 1.2. describes reporting users and the decisions taken by them on the basis of reporting. The users are existing and prospective investors, lenders and other creditors (for brevity we will call them "users").

1.2. The decisions described in article 1.2 depend on the returns that they expect from an investment in those instruments; for example dividends, principal and interest payments, or market price increases. Expectations about their returns depend on their assessment of the amount, timing of future net cash inflows to the entity and on their assessment of how efficiently and effectively the entity's management and governing board have discharged their responsibilities to use the entity's resources. They need information which allows them to make such an assessment.

This article also describes users, more specifically, the expectations of users regarding their investments. Shareholders count upon dividends and increase of share market price, and creditors count upon repayment of the principal and payment of interest.

1.3. In order to perform the assessment described in art. 1.3 users need the following information:

(a) the economic resources of the entity, claims against the entity and changes in those resources and claims; and

(b) how efficiently and effectively the entity's management and governing board have discharged their responsibilities to use the entity's economic resources.

This article describes the contents of reporting generally and uses uncommon terms. Only chapter 4 states that economic resources of the entity are understood as its assets, and claims concerning such resources - e.g. liabilities, and changes in those resources - e.g. income, expenditures and other capital changes.

1.4. Many users cannot require reporting entities to provide information directly to them and must rely on general purpose financial reports. Consequently, they are the primary users to whom general purpose financial reports are directed.

This article describes users again. Everybody who cannot require a company to furnish additional information and can rely only on general purpose financial reports are primary users. First of all, such users are represented by small investors and creditors.

So, the semantic analysis of the first two CFFR paragraphs shows that the "objective of financial reporting" is actually understood to mean financial reporting users. This is an implication of the organisation theory: each user group

\footnotetext{
9 "According to M. Mathews and M.H.B. Perera, the accounting theory has been chosen by a cohort from the American Accounting Association as an example of an internationally-oriented program of accounting study. The course program was made available to approximately five hundred colleges and universities all over the world" [8, p. 11].

${ }^{10}$ For around two decades, D. Solomons was a leading maker of CFFR in the USA and England, an author of SFAC2. D. Solomons is on S. Zeff's short list of professionals, called "the intellectual backbone of CFFR" by this historian [4, p. 313].

${ }^{11}$ The word we have crossed out was added by the translator and is not used in the original text of CFFR-2018 (in English).
} 
has its reporting, theory and terminology. It rules out the possibility of standardisation of reporting. The solution to this problem is defined in art. 1.8:

1.8. Individual primary users have different, and possibly conflicting, information needs and desires. The Board, in developing financial reporting standards, will seek to provide the information set that will meet the needs of the maximum number of primary users.

According to art. 1.8, one "information set" is made for all users, in spite of their "different, and possibly conflicting, information needs", i.e. one type of reporting which meets the needs of each user group as much as possible. It is a solution to the standardisation problem and, at the same time, negation of the organisation theory and interpreting users as the fundamental basis of CFFR.

\section{The Main Contradiction of CFFR}

Our above semantic analysis of the first few articles of CFFR indicates that two different theories are used as the theoretical basis of CFFR: the organisation theory [12, p. $5]$ and the residual equity theory [11, p. 483]. The organisation theory is used to state the fundamental concept of CFFR, and the residual equity theory is used to define the elements of financial reporting in chapter 4 of CFFR-2018. It is the main contradiction of CFFR.

Obviously, the conceptual framework of financial reporting should rest on a uniform theoretical basis. It is impossible to use the organisation theory for this purpose: it requires several types of reporting, which is a process incompatible with standardisation. The residual equity theory is compatible with standardisation to the same extent as the proprietary theory. Let us try to solve the problem of choice between these two theories on a pragmatic basis.

\section{Pragmatic Approach to Choosing the Theoretical Basis of CFFR}

In our opinion, in choosing the basic theory (and corresponding reporting) we should be guided by two criteria: 1. Understandability of financial reporting and its theory for users.

2. The orientation of reporting and theory, in the first place, to the information needs of users which plays a pivotal role in a company and bear the greatest risks in case of bankruptcy.

Let us substantiate these criteria.

\section{Understandability of Financial Reporting as the Main Qualitative Characteristic}

Let us ask the question: which qualitative characteristic of financial reporting is of most importance? At various times, this question has been answered differently. In the opinion of the authors of CFFR-1989, the main qualitative characteristic of reporting is its understandability for users. " 25 . The main quality of information presented in financial reporting is its understandability for users".
Note that the reporting should be comprehensible for users, not professionals. There is a corollary here: reporting is made for users, not accountants, i.e. for the persons and entities which take risk-related economic decisions on the basis of reporting.

However, CFFR-2010 and CFFR-2018 state another point of view. In these editions, all qualitative characteristics are divided into two categories: a) fundamental and b) enhancing. The fundamental characteristics are relevance and faithful representation. Less important second-rate characteristics which just make financial information more useful are comparability, verifiability, timeliness and understandability:

2.4. Financial information should be relevant and faithfully represented in order to be enhancing. Comparability, verifiability, timeliness and understandability of financial information makes it more enhancing.

As we can see, understandability in CFFR-2018 (as well as in CFFR-2010) is defined as a second-rate qualitative characteristic and is the last in the list. The main qualitative characteristic of financial reporting is considered to be its relevance, i.e.:

2.6. "... the capability to have a significant impact on the decisions taken by users".

Based upon art. 2.4, even incomprehensible financial information is useful if it is relevant and faithfully represented. This does not seem right. In our opinion, information which is incomprehensible to its recipient is akin to information noise, not information; it impedes decisions instead of helping to take them. An attempt to take decisions on the basis of "incomprehensible information" may be a success only incidentally. Therefore, the word "significant" we have underlined in art. 2.6 should be replaced with "correct". So, the main qualitative characteristics of financial reporting will be faithful representation and understandability.

The requirements to understandability of financial reporting are of special relevance because according to art 1.5 of CFFR 2018, their primary users are the persons and entities which cannot require reporting entities to provide information directly to them. They comprise individual persons who have purchased at least several shares or bonds, and who probably have no experience in business activities or economic education. Financial reporting should be comprehensible to such users as well.

Probably, the makers of CFFR 2010 and 2018 considered this objective unattainable, but did not declare it. One way or another, instead of trying to make financial reporting more comprehensible, they downgraded understandability. In CFFR-2010, among qualitative characteristics, understandability is transferred from the first position to the last. CFFR-2018 made another step towards it: item "(f) assist users of financial reporting in interpretation of the information presented in financial reporting" which was in CFFR-1989 and CFFR-2010 was withdrawn from the 'Purpose and Status' section.

As a result, CFFR-2018 (art. SP1.1) is intended only for professionals: standard makers and persons who draw 
up reports, while users for whom financial reporting is made are left to interpret the data at their own discretion. However, users are recommended to resort to consultants (art. 2.36). In such cases small investors and creditors will be users of paid consulting services instead of financial reporting. Besides this, it is possible that consultants will also experience problems interpreting reporting data. This can be seen by an example.

In 1999 the Accounting Standards Board (ASB) of Great Britain published the first edition of its national CFFR, titled 'Statement of Principles for Financial Reporting.' The chairman of ASB, D. Tweedie explained the change of the title as follows: "The title Conceptual Framework will be confusing for many accountants who have not studied the accounting theory" (cit. ex: 4, p. 307). Apparently, the accounting theory as it is introduced in Great Britain is so difficult to understand even for professionals, that the words "theory" or "conceptual framework" perplex them. In order to make reporting comprehensible for users, not just professionals, it is necessary to introduce changes in the theoretical basis. The case here is that makers of all three CFFR international editions were under the strong influence of their American predecessors and, as they admitted, introduced only superficial changes: "The initial FASB's project for making CFFR was not planned properly, alternatives were not considered thoroughly enough, and in reviews defects of the initial CFFR idea migrated to new editions uncorrected" [6, p. 375].

In our opinion, it is necessary to go back to the 1989 statements: a) CFFR, among other things, is intended to assist users in interpretation of financial reporting data and b) understandability is the main qualitative characteristic of financial reporting. Although in CFFR-1989 these were just declarations. Below we offer some actions to implement them.

\section{Owners as the Principal Users of Financial Reporting}

According to our reckoning, company owners should be considered the principal users of financial reporting. Owners are participants of partnerships, ordinary shareholders, (i.e. the persons who bear the greatest risks in case of business failure) and who receive remuneration by a leftover principle. Preference shareholders are not owners because they bear less risks. Moreover, any bond holders and other creditors are not considered owners. Let us articulate some arguments for this statement.,

First, owners play the most important role in corporate activities. They establish a company, sign agreements with managers and assign them the parameters of their job duties. They are the main force of the national and global capitalist economy.

Second, owners are one of the most numerous user groups because the majority of entities are partnerships. In the USA, out of 4.9 million entities, only 17 thousand traded shares publicly (and could issue securities with functions of both equity and debt instruments) [15, p. 231]. As for other companies, their owners are mainly the ones who need their reporting. Ordinary shareholders of the companies listed in the stock exchange are also owners.

Third, according to widespread opinion, reporting which meets owners' needs also meets the main needs of other user groups. It is indicated, for example, in the report made by the research group of M. Trueblood (1973) which formed the basis for SFAC1, that: "Information needs of investors and creditors are almost identical. Both groups are concerned with the company's ability to generate cash flows [cit. ex: 4, p. 284].

A similar opinion is expressed in CFFR-1989 (art. 10): "As long as investors are capital providers for a company, furnishing the information which meets their needs will also meet the majority of needs of other financial reporting users". Therefore, investors are understood as subjects contributing risk capital (art. 9 (a)), not suppliers and other trade creditors. In 1999, the first edition of British CFFR asserted the following: "Financial reports focused on investors' interests meet common interests of all users related to financial indicators and financial status of a company" [24, art. 1.11].

Let us substantiate this opinion. As noted above, owners get remuneration by a leftover principle, i.e., they are the last ones after all other reporting users entitled to it. Consequently, what is good for owners is good for other users. The owners' remuneration comprises dividends paid if profit has been generated and sufficient liquidity has been achieved. Fulfillment of these two conditions guarantees remuneration to all other users of reporting.

\section{Proprietary Theory as the Theoretical Basis of CFFR}

The proprietary theory matches both criteria: it is directed to the principal users of financial reporting and is the simplest to understand. An extended rationale of the latter thesis may be subject to a separate detailed research. Here, we will restrict ourselves to one argument. Historians are of the unanimous opinion that accounting was created by owners to meet their needs. Therefore the proprietary theory is a natural accounting theory, while all other theories are artificial and are essentially adaptations of accounting to functions extrinsic to it.

Also noteworthy is the fact that recognising the proprietary theory as the theoretical basis of CFFR does not require significant innovation, all it takes is going back to a well-known theory.

\section{Conclusions}

There is a reason that the Conceptual Framework for Financial Reporting is difficult to understand even for professionals. Neither edition of CFFR states the theoretical basis on which the provisions of the documents rely. Instead, readers are offered to base their understanding upon the fundamental concept of CFFR defined in the first paragraph. It is asserted that all other CFFR aspects flow logically from this concept. However, the syntactic analysis of the denomination of this concept, the "objec- 
tive of financial reporting", revealed its self-contradictoriness. The semantic analysis showed that this denomination does not correspond to the concept meaning. So, from the very beginning readers are misled and deprived of the clues to a coherent study of the document.

In this paper, we attempt to define the theoretical basis and actual fundamental concept of CFFR, and analyse them from a critical point of view, and offer an alternative.

The research findings led to the conclusion that CFFR makers relied on two different theories: the organisation theory and the residual equity theory. The organisation theory was used to define the fundamental concept of CFFR, and the residual equity theory - to identify the elements of financial reporting. This is the main contradiction of CFFR.

The identification of causes of such inconsistency requires a separate research. Whatever be the causes, the current state of things is unacceptable. We support the opinion of representatives of the American Accounting Association (AAA) who, in order to eliminate CFFR drawbacks, offer “... to start with constructing a most general accounting theory, and then, on its basis, develop CFFR and individual standards" $[15$, p. 238]. We would like to add that it is reasonable to state the basic theory in the first chapter of CFFR and interpret it as a logical beginning of this document. Additionally, we presume that instead of making a new theory, one should resort to the well-known proprietary theory.

The advantages of the proprietary theory are its simplicity, its orientation to the interests of the main user group company owners, and its capability to meet information needs of all other user groups. In this case, the fundamental concept of CFFR should be the definition of financial reporting directed towards owners' interests.

Implementation of the above propositions will significantly enhance the understandability of CFFR, and the financial reporting and quality of economic decisions taken by all user groups.

These propositions are open to discussion; and we will be glad for commentary on them.

\section{Limitations}

This paper looks at the causes of use of the term "objectives of financial reporting" in CFFR, and does not study at all the reasons for the prevalence of the organisation theory in the US. The main reason is the limited length of this paper. In our opinion, a detailed analysis of each of the above problems will require at least one large research paper.

Other causes include the complexity of the above problems and the insufficient attention paid to them by English-speaking authors. So, in the monograph by E. Hendriksen and M. van Breda [11] consisting of almost 600 pages, the organisation theory and hybrid theories are described on only one or two pages. An equally large monograph by M. Mathews and M. Perera [8] does not mention this theory at all.
As for the term "objectives of financial reporting" S. Zeff [4] paid the most attention to it, but he merely mentioned the time of its first use, and the existence of criticism, without stating the reasons for the controversial wording and his own opinion. The majority of authors take no notice of the self-contradictoriness of this term, or criticism against it, or its inconsistency with the meaning of the concepts which it describes.

The above reasons motivated our focus in this paper on the critical analysis of historically-developed provisions of CFFR.

\section{References}

1. Conceptual framework for financial reporting. Ministry of Finance of Russia. 2018. URL: https://minfin.gov.ru/ru/ document/?id_4=117374-kontseptualnye osnovy_predstavleniya_finansovykh_otchetov_ dokument_kontseptualnye_osnovy_predstavleniya_ finansovykh_otchetov_prinyat_sovetom_po_msfo._ nastoyashchaya_publikats (accessed on 20.07.2020). (In Russ.).

2. Framework for the preparation and presentation of financial statements. Moscow: Askri-ASSA; 1999. 1135 c. (In Russ.).

3. Conceptual framework for financial reporting. 2010. URL: https://www.minfin.ru/common/upload/ library/2014/06/main/kontseptualnye_osnovy_na_ sayt_bez_predisloviya_-_kopiya.pdf (accessed on 20.07.2020).

4. Zeff S.A. The objectives of financial reporting: A historical survey and analysis. Accounting and Business Research. 2013;43(4):262-327. DOI: 10.1080/00014788.2013.782237

5. Malafeeva T.N. The emergence and development of the convergence process of the two types of standards: IFRS and US GAAP. Korporativnye finansy $=$ Journal of Corporate Finance Research. 2016;10(3):70-83. DOI: 10.17323/j.jcfr.20730438.10.3.2016.70-83

6. Dennis I. What is a conceptual framework for financial reporting? Accounting in Europe. 2018;15(3):374-401. DOI: $10.1080 / 17449480.2018 .1496269$

7. Whittington G. Harmonisation or discord? The critical role of the IASB conceptual framework review. Journal of Accounting and Public Policy, 2008;27(6):495-502. DOI: 10.1016/j. jaccpubpol.2008.09.006

8. Mathews M., Perera M.H.B. Accounting theory and development. Melbourne: Nelson; 1996. 402 p. (Russ. ed.: Mathews M., Perera M.H.B. Teoriya bukhgalterskogo ucheta. Moscow: YuNITI; 1999. 663 p.). 
9. Solomons D. Guidelines for financial reporting standards. London: The Institute of Chartered Accountants; New York: Garland Publishing; 1989. $77 \mathrm{p}$.

10. Whittred G.P., Zimmer I.R. Financial accounting: Incentive effects and economic consequences. Sydney: Holt, Rinehart and Winston; 1988. 341 p.

11. Hendriksen E.S., van Breda M.F. Accounting theory. Homewood, IL: Irwin, 1992. 905 p. (Russ. ed.: Hendriksen E.S., van Breda M.F. Teoriya bukhgalterskogo ucheta. Moscow: Finansy i statistika; 1997. 576 p.).

12. IASB/FASB Exposure draft: An improved conceptual framework for financial reporting. Chapter 1: The objective of financial reporting. Chapter 2: Qualitative characteristics and constraints on decision-useful financial reporting information. 2008. URL: https://library.croneri.co.uk/cch_uk/iast/ iasedim0806-200806\#toc-1-1

13. Kovalev V. Kovalev Vit.V. Conceptual framework of accounting: Logic of evolution. Vestnik SanktPeterburgskogo universiteta. Ekonomika $=S t$ Petersburg University Journal of Economic Studies (SUJES). 2015;(4):117-152. (In Russ.).

14. Dichev I.D. On the balance sheet-based model of financial reporting, Accounting Horizons. 2008;22(4):453-470. DOI: 10.2308/acch.2008.22.4.453

15. Benston G.J., Carmichael D.R., Demski J.S., Dharan B.G., Jamal K., Laux R., Rajgopal, S., Vrana G. The FASB's conceptual framework for financial reporting: A critical analysis. Accounting Horizons. 2007;21(2):229-238. DOI: 10.2308/acch.2007.21.2.229

16. Jones $\mathrm{T}$. The principles and practice of book-keeping, embracing an entirely new and improved method of imparting the science: With exemplifications of the most concise and approved forms of arranging merchants' accounts. New York: Wiley and Putnam; 1841. $160 \mathrm{p}$.

17. Foster B.F. A concise treatise on commercial bookkeeping: Elucidating the principles and practice of double entry, and the modern methods of arranging merchants' accounts. Boston: T.R. Marvin; 1846. 184 p.

18. Hügli F. Die buchhaltungs-systeme und buchhaltungsformen. Bern: K.J. Wyss; 1887. 678 p.

19. Schär J.F. Experience in scientific development of accounting. Transl. from German. Schetovodstvo. 1892;(1):2-4, (3):34-35, (5):60-61, (22):270-272. (In Russ.).

20. Hatfield H.R. Accounting: Its principles and problems. New York: D. Appleton and Company; 1927. $566 \mathrm{p}$.
21. Tsygankov K.Yu. Theory and methodology of capital accounting. Doct. econ. sci. diss. Novosibirsk: Novosibirsk State University of Economics and Management; 2009. 303 p. (In Russ.).

22. Van Mourik C. The equity theories and financial reporting: An analysis. Accounting in Europe. 2010;7(2):191-211. DOI: $10.1080 / 17449480.2010 .511885$

23. Mattessich R. Two hundred years of accounting research. An international survey of personalities, ideas and publications (from the beginning of the nineteenth century to the beginning of the twenty first century). Abingdon, New York, Routledge; 2008. 609 p. (Routledge New Works in Accounting History. Vol. 8).

24. Statement of principles for financial reporting. Statement. London: Accounting Standards Board; 1999. 151 p. URL: https://www.frc.org. uk/getattachment/31cb1973-82a6-439b-bf448 fffad5b20da/Statement-of-Principles-for-FinancialReporting-1999.pdf 